\title{
Universiteit
}

Leiden

The Netherlands

\section{The Text of Isaiah and its Early Witnesses in} Hebrew

Kooij, A. van der

\section{Citation}

Kooij, A. van der. (2006). The Text of Isaiah and its Early Witnesses in Hebrew. In . Leiden. Retrieved from https://hdl.handle.net/1887/10536

Version:

Not Applicable (or Unknown)

License:

Leiden University Non-exclusive license

Downloaded from: $\quad$ https://hdl.handle.net/1887/10536

Note: To cite this publication please use the final published version (if applicable). 


\section{Sôfer Mahîr}

Essays in Honour of Adrian Schenker

Offered by Editors of

\section{Biblia Hebraica Quinta}

\section{Edited by}

Yohanan A.P. Goldman, Arie van der Kooij and Richard D. Weis

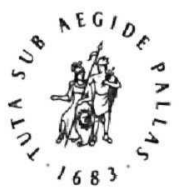

BRILL

LEIDEN • BOSTON

2006 


\section{CONTENTS}

Preface

vii

List of contributors

ix

Introduction

Robert AlthanN

Reflections on the Text of the Book of Job

Piet B. Dirksen

Septuagint and Peshitta in the Apparatus to Canticles in Biblia Hebraica Quinta

Natalio Fernández Marcos

The Genuine Text of Judges

Anthony Gelston

Some Difficulties Encountered by Ancient Translators

Agustinus Glanto

Notes from a Reading of Daniel 2

Yohanan A. P. Goldman

Le texte massorétique de Qohélet, témoin d'un compromis théologique entre les 'disciples des sages' (Qoh 7,23-24; $8,1 ; 7,19)$

INNOCENT Himbaza

Textual Witnesses and Sacrificial Terminology in Leviticus $1-7$

Philippe Hugo

Le Grec ancien des livres des Règnes. Une histoire et un bilan de la recherche

ArIE van der KoOIJ

The Text of Isaiah and its Early Witnesses in Hebrew

Johan Lust

The Ezekiel Text 
David Marcus

How $B H Q$ Differs from $B H S$ in the Book of Ezra-

Nehemiah

\section{Carmel McGarthy}

A Comparative Study of the Masorah Magna and Parva of the Book of Deuteronomy as attested in the Leningrad and Madrid M1 Manuscripts

GERARD J. Norton

A Diplomatic Edition of the Psalter?

MARTIN Rösel

Die Textüberlieferung des Buches Numeri am Beispiel der Bileamerzählung

Magne S

Some Reflections on the Use of paseq in the Book of Esther

\section{ROLF SCHÄFER}

Der ursprüngliche Text und die poetische Struktur des ersten Klageliedes (Klgl 1): Textkritik und Strukturanalyse im Zwiegespräch

JAN DE WAARD

Lexical Ignorance and the Ancient Versions of Proverbs

RichaRD D. WEIS

The Textual Situation in the Book of Jeremiah

Biblical Index 


\title{
THE TEXT OF ISAIAH AND ITS EARLY WITNESSES IN HEBREW
}

\author{
Arie van der Kooij
}

A main characteristic of the new edition, the Biblica Hebraica Quinta $(B H Q)$, is the use of the textual evidence from manuscripts discovered in Qumran and other places in the Dead Sea region. From the point of textual criticism these texts are of great significance. In the period before Qumran the critical assessment of the Masoretic text (M) was mainly done on the basis of the early versions - translations, which by their nature do not provide direct evidence of the Hebrew text. Instead, the underlying parent text has to be reconstructed first, a procedure which in many instances creates a great deal of uncertainty. Most biblical texts of Qumran, however, are written in the language of the Hebrew Bible, Hebrew or Aramaic, thus representing direct evidence of the text. Moreover, they date from the earliest period in which the biblical text is attested, viz., the third century B.c.E. up to the second century c.E. In comparison to the other witnesses of the early period - the Septuagint $(G)$ and the Samaritan Pentateuch (Smr) - the Qumran texts have an additional value in that they constitute manuscript evidence that goes back to this early period directly, and not indirectly, i.e., via a reconstruction of the text of a witness on the basis of manuscripts of a later date, as is the case with the $\mathbf{G}$ and Smr.

Given the great significance of the biblical texts from the Dead Sea region it is, on the other hand, frustrating that in general the evidence is so fragmentary. Fortunately, the book of Isaiah - my part in the Quinta project - is attested by a large number of mostly fragmentary manuscripts from Qumran (22), but also by one complete scroll (IQIsa ${ }^{a}$ ), and another one that has been preserved for a fifth of the book $\left(\right.$ lQIsa $\left.^{b}\right) .^{1}$ As a whole the Qumran evidence now avail-

\footnotetext{
${ }^{I}$ For a listing of the evidence see, for example, M. G. Abegg, Jr., "IQIsa ${ }^{x}$ and
} 
able is very important, the more so since G-Isaiah - a version also going back to the early period - represents an indirect witness which, due to its nature as a 'free' translation, causes much uncertainty as far as the underlying Hebrew text is concerned. Consequently, the evidence of the Dead Sea region will play a leading role in the selection of cases for the critical apparatus of Isaiah in $B H Q$.

In this contribution in honour of Adrian Schenker, I like to discuss a number of variant readings in Isaiah which are attested by two or more Qumran Mss.

In some cases the available evidence provides us with an interesting variety of readings. Here are some examples.

\section{5:19 M תקרב ותבואה 4QIsa; 1QIsa}

The lengthened form of the third person sing., חבואה (cohortative), is rare in $\mathbf{M}$ (cf. יחישה in the same verse). ${ }^{2}$ The reading be due to influence of תבריאה. ${ }^{3}$ It is difficult to say which text tradition is to be preferred here.

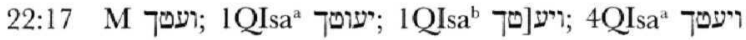

The Qumran witnesses reflect a tendency related to later Hebrew. ${ }^{4}$

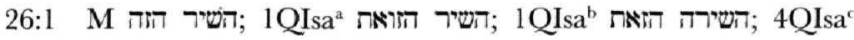 השיר ה[זה}

The reading of $\mathbf{M}$ is a hapax, whereas that of $1 \mathrm{QIsa}^{\mathrm{b}}$ is the usual one in $\mathbf{M}$ (e.g., Exod 15:1; Num 21:17). 1QIsa ${ }^{a}$ offers a mixed reading. The reading of $\mathrm{M}\left(=4 \mathrm{QIsa}^{c}\right.$, with some uncertainty) is the more difficult one and hence the preferable one. ${ }^{5}$

1QIsab: a Rematch," in E. D. Herbert and E. Tov (eds.), The Bible as Book: The Hebrew Bible and the fudaean Desert Discoveries (London, 2002), 222f. In addition, there are a number of citations from Isaiah in Q-documents such as the pesharim.

${ }^{2}$ See H. Bauer and P. Leander, Historische Grammatik der hebrässchen Sprache des Alten Testamentes (Halle, 1918; repr. Hildesheim, 1965), §56u", 59p.

${ }^{3}$ E. Y. Kutscher, The Language and Linguistic Background of the Isaiah Scroll $\left(1 \mathrm{QIsa}^{4}\right)$ (STD7 6; Leiden, 1974), 328.

${ }^{4}$ See Kutscher, Language, $357 \mathrm{f}$.

${ }^{5}$ Cf. D. Barthélemy, Critique Textuelle de l'Ancien Testament, vol. 3, Ézéchiel, Daniel et les 12 Prophètes (OBO 50/3; Fribourg \& Göttingen, 1992), cviii. (= CTAT 3). 
46:10 M אחרית; 1QIsa ${ }^{b}=$ M; 1QIsa ${ }^{a}$ תמות;

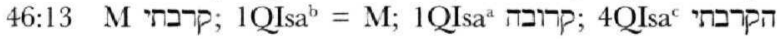

In both cases $M=1$ QIsab represents the better reading. The reading (1QIsa $\left.{ }^{a}\right)$ may be an error, ${ }^{6}$ or a plural form conveying the same meaning as the reading of 4QIsa ${ }^{a}$, ing, which is not attested in $\mathbf{M}$, is also found in 1QIsa ${ }^{a}$ 41:22. Compare the plural form ראשוח in $41: 22 ; 42: 9$.)

As to Pרבת, the reading of 1 QIsa ${ }^{a}$ may be due to influence of $56: 1$, whereas the reading in $4 \mathrm{QIsa}^{\circ}$ is an adaptation to the more common usage in biblical Hebrew (the hifil of paccurs many times in $\mathrm{M}$; the piel, however, is rare).

Of particular interest are those cases where more than one biblical Qumran Ms of Isaiah attests the same variant reading against $\mathbf{M}$. The shared evidence may enhance the possibility that the Qumran Mss attest a reading which is earlier and better than the Masoretic one. On the other hand, it is one of the principles of textual criticism that mss should not be counted, but weighed, a rule which also applies to the date of mss. Each case therefore should be evaluated individually. First, we will deal with some cases of $1 \mathrm{QIsa}^{\mathrm{a}}=1 \mathrm{QIsa}^{\mathrm{b}}$ against M, secondly, with cases of 1 QIsa ${ }^{a}=4 Q \mathrm{Ms}$, and thirdly, with cases of 1 QIsa ${ }^{a}=$ two Qumran mss.

\section{A. $1 Q I s a^{a}=1 Q I s a^{b} \neq M$}

\section{5:2 M הדורים; 1QIsa הרים 1QIsab הרורים}

Hebrew הדורים presents a difficulty since its meaning is uncertain and disputed ('spiral roads', 'uneven places'?). ${ }^{8}$ Scholars, therefore, have argued that the variant reading attested by 1 QIsa ${ }^{\mathrm{a}}$ (1QIsab?) and G, "mountains", is to be preferred, as it makes good sense in the context. ${ }^{9}$ However, the difficulty with this solution is that the

${ }^{5}$ Kutscher, Language, 366.

7 A. van der Kooij, Die alten Textzengen des Jesajabuches (OBO 35; Freiburg \& Göttingen, 1981), 95.

${ }^{8}$ For a detailed discussion, see J. L. Koole, Isaiah, Part 3, vol. 1, Isaiah 40-48 (HCOT; Kampen, 1997), 434-435.

${ }^{9}$ See, e.g., D. Barthélemy, CTAT 3, cviii. 
reduplicated plural (הרריש; see also 1QIsaa 42:11) does not occur in biblical Hebrew in the absolute state. ${ }^{10}$ As has been argued by other scholars, M-Kethib may well represent the original reading if taken in the sense of 'the walls', in line with Akkadian duru. ${ }^{11}$ Contextually, this would fit even better because of the 'doors of bronze' and 'bars of iron' in the rest of the verse.

49:7 M יהוה; 1QIsa = 1QIsab

According to Barthélemy ${ }^{12}$ the short reading of $\mathrm{M}$ is the better one. The long expression occurs at some places (thirteen) in M Isaiah where it is also attested by 1 Q Isa ${ }^{a}$ (except in a few instances [49:22; $50: 5 ; 52: 4 ; 61: 11])$. It is difficult to say which reading in $49: 7$ is the primary one, but it may well be that the long reading of $1 \mathrm{QIsa}^{\mathrm{a}}=$ 1QIsa ${ }^{b}$ is due to influence of $48: 16$.

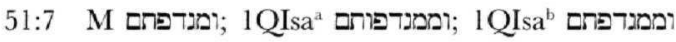

The second mem in $1 Q I s a^{a}$ has been added, in superscript, by a second hand. The feminine plural in $\mathrm{M}$ is a hapax. Instead of the gittulform in M both Qumran witnesses offer a miqtal-form, which seems to be an adaptation to a more usual form.

53:1 על; 2 Q 1 QIsa $^{a}=1$ QIsa $^{b}$

The nifal of גלד על על על מל occurs here and in Exod 20:26. The variant reading in both 1QIsa (the 'alep was corrected here from 'ayin) and 1 QIsa ${ }^{b}$ is in line with the usage at other places (e.g., Gen 35:17; 1 Sam 3:7, 21). The same is true for Smr Exod 20:26 (אליו). M seems to be the better reading.

54:3 M יירש; 1QIsa

The plural form may be an assimilation to ישיביר , ${ }^{13}$ but it is also possible that this form was introduced because of the subject זרע, 'seed' (M reads זרעך גוים יירש). For a similar case see 57:3.

\section{5:11 M את אשר אשר}

The plus in both Qumran mss is probably due to harmonization with the first half of v. $11 \mathrm{~b}$ (אח אשר חפצתי).

\footnotetext{
${ }^{10}$ Koole, Isaiah, 435.

"See C. H. Southwood, "The problematic hadurim of Isaiah xlv 2," VT 25 (1975), $801 f$.

${ }^{12}$ Barthélemy, CTAT 3, cix.

13 Barthélemy, Ibid.
} 


\section{8:3 M נפשנו 1QIsaa נפשותינו 1QIsa}

The plural form in both Qumran mss is an adaptation to the idiom as found in texts such as Lev 16:29, 31 and Num 29:7.14

\section{2:6 M תמיר; 1QIsa ${ }^{a}=1$ QIsa $^{\mathrm{b}}>$}

The Hebrew תמיד, which in M follows the expression 'all the day and all the night', may well have been regarded as superfluous.

B. $1 Q I s a^{a}=4 Q \neq M$

\section{0:32 M בית 1QIsa ${ }^{a}=4$ ב Isa $^{\mathrm{a}}$ ב}

The reading of the Qumran mss agrees with $M$ Qere. The latter, "(the mountain) of the daughter (of Zion)", is the original one (cf. Isa 16:1). For this reading, see also 4Qpisa ${ }^{a}$ 5-6, l. 4.

\section{1:8 M צפעוני; 1QIsa}

The plural reading of the Qumran mss is the secondary one. ${ }^{15}$ For a similar case see 1 QIsa ${ }^{a}$ Isa 59:5.

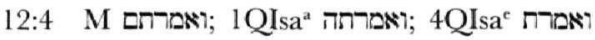

The singular in the Qumran mss seems to be an assimilation to v. 1 .

\section{9:9 M חזרי 1QIsa}

$\mathrm{M}$ is difficult here. ${ }^{16}$ The reading of the Qumran mss seems to be the preferable one - "(and weavers) shall wax pale" (of the root רוש same verse (cf. 29:22).

\section{9:18 M החרסס 1QIsaa = 4QIsa}

As has been argued by scholars, the Qumran mss offer the better reading here: "(the city) of the sun" (instead "the city of destruction" in $\mathrm{M}) .^{18}$

${ }^{14}$ Cf. Kutscher, Language, 398; Barthélemy, CTAT 3, cx.

${ }^{15}$ See Kutscher, Language, 399.

${ }^{16} \mathrm{DCH}$ suggests: 'תור, "white stuff'. The reference to 4QpIsa ${ }^{\mathrm{c}}$ (4Q163), however, is misleading since the reading involved is not attested by the $\mathbf{M s}$, but has been reconstructed to fill in a lacuna.

${ }_{17}$ See, e.g., Kutscher, Language, 235; D. Barthélemy, Critique textuelle de l'Ancien Testament, vol. 2, Isaïe, férémie, Lamentations (Fribourg \& Göttingen, 1986), 139. (= CTAT 2)

${ }^{18}$ See, e.g., D. Barthélemy, CTAT 2, 143-150; van der Kooij, Textzeugen, 216. 


\section{4:4 M אמללו אמלל 1QIsa}

The $\mathrm{M}$ reading may represent the primary one, ${ }^{19}$ but in this instance the evaluation of the evidence depends on the interpretation of the word that follows, מרום. (M reads אמללו מרום עם ה-אריץ.) If one takes this word, together with $\mathbb{E}$, in the sense of people that are in a high position (cf. Job 5:11), then the plural reading is fitting, but if מרום is understood in the sense of a high place, the singular reading is more plausible.

\section{4:6. M תורו}

The Qumran mss offer a reading here which is the same as in 19:9 (see above). The M reading is best explained as a form of תרה נת', "to diminish in number' (cf. the parallel, נשאר). It fits the context better than the verb חוז. ${ }^{20}$

\section{6:12 M תשפת; 1QIsa}

As is often the case, particularly in 1 QIsa ${ }^{a}$, a common word - in this case שפט - שפ - שפת מ. ${ }^{21}$ The veen substituted for a rarer one שפ occurs at a few other places (2 Kgs 4:38; Ezek 24:3; Ps 22:16) and carries the meaning 'to set'.

\section{2:11 M ישאי; 1QIsa}

The verbal form is followed by מדבר, 'the desert', and it therefore seems appropriate to have a singular form here. However, it may well be that the $\mathrm{M}$ reading is the better one since contextually speaking (see v. 11b) the inhabitants of the desert are meant.

\section{9:7 M לבזוי 1QIsa}

The $M$ reading לבזה is a difficult one since its vocalization (infinitive construct) does not seem to make sense. Rather, one expects an adjective, or participle (cf. מחעב) as continuation of "Thus says the Lord to....". One therefore could read the Kethib בזה as an active participle, as some scholars prefer (cf. G), but most scholars agree that a passive sense is the more plausible understanding of the verse. ${ }^{22}$ Consequently, the variant reading בזור is likely to be the primary

\footnotetext{
${ }^{19}$ So Barthélemy, CTAT 2, 174.

${ }^{20}$ Cf., for example, H. Wildberger, Jesaga (BKAT 10; Neukirchen-Vluyn, 1972-1982), 915.

${ }^{21}$ See Kutscher, Language, 293.

${ }^{22}$ See Koole, Isaiah, $31 \mathrm{f}$.
} 
reading, as many scholars believe. ${ }^{23}$ Alternatively, since this reading may have been due to a harmonization to מתעב, and since the collocation לבזו" suggests the meaning, 'despised by someone"24 rather

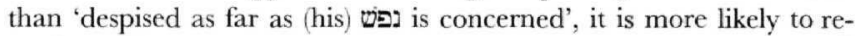

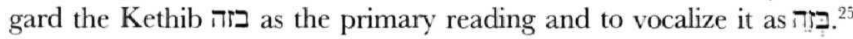

\section{C. $1 Q I s a^{a}=$ Two Qumran mss $\neq M$}

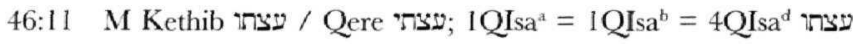

The Qumran Mss support $\mathbf{M}$ Kethib which is the primary reading.

48:11 M יחל איחל

(4QIsa ${ }^{d}$ with a second 'alep in superscript)

McCarthy has argued that the variant of the Qumran mss testifies to the primary reading since $M$ represents here an example of a tiqquin, a theological correction. The phrase "How should I be pro-

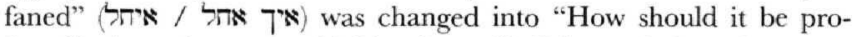
faned", in order to avoid blasphemy. ${ }^{26}$ Other scholars, however, consider $M$ to be the better reading. The verbal form ( $\rightarrow$ ) should be understood as referring to "my name" in v. 9 ("How should my name be profaned"). Furthermore, according to this view, the first person singular in the Qumran mss is easily understood as a change due to the context. ${ }^{27}$ The plene spelling of the reading in the Qumran mss seems to be in favour of this opinion because, if the first person singular were the original reading, one would expect the form ל ject!). So there is reason to believe that the $M$ reading is the primary one.

The form in the Qumran mss may be regarded as plene of לח (so McCarthy), or as a piel form of the verb 'r্য', 'to wait'. ${ }^{28}$ The

${ }^{23}$ Koole, Isaiah, 32.

${ }^{24}$ Compare עם בזו" in Ps 22:7.

${ }^{25}$ Cf., for example, Barthélemy, CTAT 2, 358-360; M. C. A. Korpel and J. C. de Moor, The Structure of Classical Hebrew Poetry: Isaiah 40-55 (OTS 41; Leiden, 1998), 401 .

${ }^{26}$ C. McCarthy, The Tuqqune Sopherim and Other Theological Corrections in the Masoretic Text of the Old Testament (OBO 36; Freiburg \& Göttingen, 1981), 207-209. See also Barthélemy, CTAT 2, 354f; Korpel and De Moor, Isaiah 40-55, 364.

${ }^{27}$ See, e.g., Kutscher, Language, 242; J. Koenig, L'herméneutique analogique du fudażsme antique d'après les témoins textuels d'Isaie (VTSup 33; Leiden, 1982), 373 ("une retouche par petite mutation"); Koole, Isaiah, 575.

${ }_{28}$ See Kutscher, Language, 242; P. Pulikottil, Transmission of Biblicat Texts in Qumran: The Case of the Large Isaiah Scroll IQIsa" (JSPSup 34; Sheffield, 2001), 102. 
latter interpretation makes sense if understood as "How shall I wait" (i.e., I will not wait to act for my name's sake), and not as "How shall I hope for". ${ }^{29}$

53:11-12

(1) $M$ יראה אור

(2) $\mathrm{M}$ Non; IQIsa ${ }^{a}=1$ IQIsa $^{b}=4 \mathrm{QIsa}^{\mathrm{d}}$,

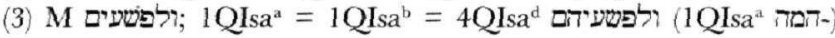

This is a most interesting situation since in three instances three Qumran Mss offer in each case the same variant reading against $M$. In view of the fact that not only the three available Qumran mss agree in each case, but also because $1 \mathrm{QIsa}^{\mathrm{b}}$ as 'pre-Masoretic' witness is part of the picture, Barthélemy is of the opinion that the Qumran readings are to be regarded as the primary ones. ${ }^{30}$ The evidence is impressive indeed, but one has also to consider and evaluate each case on its own.

(1) M "he will see"; Qumran "he will see light"

This is the most intriguing case of the three. It is disputed, however, whether the plus 'אוght', was part of the original text, or not. The expression, 'to see light', is well known in the Hebrew Bible in the sense of 'to enjoy life' (e.g., Ps 36:10). However, in our text there seems to be a relationship between 'light' and 'knowledge, insight' (דעת) since the text continues as ישבע בדעתו (M). the expression "to see light" would then convey the meaning of 'gaining insight'. Seeligmann has argued rightly that since the expression 'to see light' in this sense has no parallel in the Hebrew Bible, the plus 'light' should be regarded a secondary reading. ${ }^{32}$ In addition, one could say that the verb ראה itself carries here the connotation of gaining insight comparable to Isa 5:19; 6:9; 41:20;44:9 // עדי) ${ }^{33}$ However, the difficulty with this latter argument is that in 53:11 the verb 'to see' is followed by the verb 'to be satisfied' (שבע), and not by 'to know'. Of course, the verb שכבע is followed by בדערז, "with his knowledge", but here the question arises whether this word

${ }^{29}$ For this latter meaning, see the hifil in 1QIsa $51: 11$ (M piel).

${ }^{30}$ Barthélemy, CTAT 2, 403-407; idem, CTAT 3, cix.

${ }^{31}$ Cf. G.

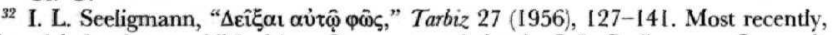
this article has been published in a German translation in: I. L. Seeligmann, Gesammelte Studien zur Hebräischen Bibel (ed. by E. Blum; FAT 41; Tübingen, 2004), 401-419.

${ }^{33}$ See, e.g., W. A. M. Beuken, Zesaja: deel II (Nijkerk, 1979); Koole, Isaiah; and De Moor and Korpel, Isaiah 40-55. 
belongs to שבעי", or rather should be taken as the first word of the next clause ("with his knowledge he will justify..." [בדעח יצדיק]). The latter option seems the more plausible one because of the suffix, for it is strange to say that the servant will be satisfied with his (own) knowledge. ${ }^{35}$

On balance then it seems that the original text read (in translation) "he will see and be satisfied". ${ }^{36}$ As has been suggested by Bonnard, both verbs are to be understood in the light of the preceding verse (v. 10) where it reads, "he will see offspring, prolong his days" (יראה זרע יאריך ימים.). As to the verb 'to be satisfied' as denoting a long life he points to texts such as Gen 25:8 (שבע), and Gen 35:29 and Job 42:17 (both שבע ימים). sion ארך ימים אשביעהו in Ps 91:16.

(2) M "sin" (sg.); Qumran "sins" (pl.)

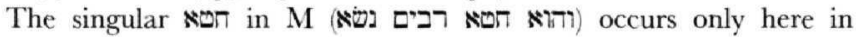
Deutero-Isaiah. According to Barthélemy, the singular represents an adaptation to the singular in v. 6 (עון) and in v. 8 (פשע). ${ }^{39}$ Koole, on the other hand, argues that the plural "is better explained as a harmonization with the plural forms in the context" (see vv. 4-5, $11 \mathrm{~b}){ }^{+0}$ So the context does not help us any further. As has been

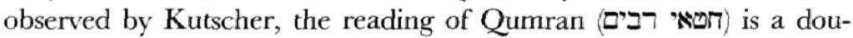
ble plural which is typical of later Hebrew (e.g., Chronicles). ${ }^{41}$ It therefore seems to be a secondary reading. ${ }^{42}$

(3) M "sinners"; Qumran "their sins"

Some consider the reading of the Qumran witnesses as the original one (e.g., Barthélemy), but it is also possible that, as Kutscher argues, this reading is due to harmonization with the first half of the line

34 So IQIsa ${ }^{2}, T$, and $\mathrm{V}$.

35. This may have been the reason why $\mathrm{G}$, followed by $\mathrm{S}$, does not offer an equivalent of the suffix.

36 For suggestions of what may have been the reason of the plus "light", see Seeligmann (due to the notion of 'light' in the sense of knowledge in texts of the Qumran community [1QSb IV 25-27; 1QH IV 27-28]); Koenig, L'herméneutique analogique, 275f. (influence of 9:1 and 50:11); Koole, Isaiah, 329 (influence of 50:10 and 9:1); and Korpel and De Moor, Isaiah 40-55, 549 (influence of 42:16).

${ }_{37}$ P. E. Bonnard, Le Second Isaïe son disciple et leurs éditeurs, Isaïe 40-66 (Paris, 1972), 278.

${ }^{38}$ Bonnard, Second Isaie, 278 note.

${ }^{39}$ Barthélemy, CTAT 2, 406.

40 Koole, Isaiah, 341.

41 Kutscher, Langwage, 399.

${ }^{42}$ For the expression 
(cf. the Qumran reading under [2]). ${ }^{43}$ It may well be that the original reading was spelled defectively (פשעם) because this would explain both interpretations - "sinners" as well as "their sin" (sg.), ${ }^{4+}$ the latter of which was changed into the plural, "their sins" (cf. [2]). For a similar case of a shift from singular to plural see 58:1: M פשעם (= IQIsa $\left.{ }^{b}\right)$ vs. IQIsa

\section{IV}

From the above analysis the picture emerges that while in a few cases shared readings in Qumran mss testify to a better text, in many cases the combined evidence turns out to be of a secondary nature in comparison to $\mathrm{M}$. This may not be surprising as far as concerns 1QIsa ${ }^{\mathrm{a}}$, but it is interesting to note that $\mathrm{Q} \mathrm{QLa}_{\mathrm{b}}^{\mathrm{b}}$, a ms that is considered to be archaic, or 'pre-Masoretic' (Barthélemy), also contains readings - albeit to a much lesser extent, which testify to tendencies such as linguistic adaptation to later Hebrew or to a more common usage in the Hebrew Bible. The same is true of Isaiah mss from Cave 4.

Thus, as far the above evidence goes, $M$ attests a textual tradition which was transmitted in the early days - third century B.C.E. up to second century C.E. - in a more strict and accurate way. This is in line with the view that there has been a situation of textual fluidity alongside textual stability, or uniformity, in the early period..$^{45}$

The Qumran mss of Isaiah referred to above reflect a practice of copying texts which was marked by linguistic adaptation and changes due to context. This mode of copying texts testifies to a scholarly interest in the language and the content of the text, ${ }^{46}$ and may have been characteristic of the production of mss for study purposes. ${ }^{47}$

${ }^{43}$ Kutscher, Language, 383.

"4 For this view see K. Elliger, "Nochmals Textkritisches zu Jes 53," in J. Schreiner (ed.), Wort, Lied und Gottesspruch: Festschrift fuir 7. Ziegler (FB 2; Würzburg, 1972), 2:143f.

${ }^{45}$ See in particular A. S. van der Woude, "Pluriformity and Uniformity: Reflections on the Transmission of the Text of the Old Testament," in J. N. Bremmer and F. García Martínez (eds.), Sacred History and Sacred Texts in Early fudaism (CBET 5; Kampen, 1992), 151-169.

46 A very interesting case is the plus "light" in Isa 53:11. The question whether this plus reflects a specific or sectarian interpretation, as has been suggested by Seeligmann, needs further investigation.

${ }^{47}$ For this phenomenon, see M. H. Goshen-Gottstein, "Biblical Manuscripts in the United States," Textus 2 (1962), 36-39. 